\title{
FAKTOR-FAKTOR YANG MEMPENGARUHI PRODUKTIVITAS TENAGA KERJA KARYAWAN PEMANEN KELAPA SAWIT DI PT. ALAM JAYA PERSADA FACTORS AFFECTING WORK PRODUKTIVITY OF OIL PALM HERVESTING EMPLOYEE IN PT. ALAM JAYA PERSADA
}

\author{
Sesilia Abdiyani ${ }^{1}$, Sri Ngapiyatun ${ }^{2}$, Faradilla ${ }^{2}$ \\ 1 Mahasiswa Pengelolaan Perkebunan \\ 2 Pengajar Politeknik Pertanian Negeri Samarinda \\ sesil9712@gmail.com
}

\begin{abstract}
Harvesting process is very important on determining the quality of CPO produced so that it can increase revenue or reciprocity toward company's development. This encourages researcher to analyze what factors influence the productivity of oil palm harvesters. This study used sample of 20 people. Sample was determined by using Non Probability Sampling technique with census method or saturated sample which used all the population as sample because the population was less than 30 people. The data were collected by questioner and interviewing the chosen respondents. Variables in this study were age (X1), education (X2), work tenure (X3), number of dependents (X4) and the dependent variable was employee's work productivity $(Y)$. The Data ws analyzed by using multiple linear regression with effective contribution test and coefficient of determination test. The result showed that age and education factors had positive affect toward employee's work productivity. Beside of that, work tenure and number of dependents had negative effect on employee's work productivity and the most dominant contribution among the four factors was the number of dependents. In addition, the value of $R$ square or the coefficient of determination showed that factors of age, education, years of service and the number of dependents together affected work productivity by $41.7 \%$ and the remaining $58.3 \%$ were influenced by other factors outside the study.
\end{abstract}

Keywords : Age, education, work tenure, number of dependentsm productivity, harvesting employee.

\section{PENDAHULUAN}

Tanaman kelapa sawit (Elaeis guinensis jacq) merupakan tumbuhan tropis golongan palma yang termasuk tanaman tahunan. Industri minyak sawit merupakan kontributor penting dalam produksi di Indonesia dan memiliki prospek pengembangan yang cerah. Industri ini juga berkontribusi dalam pembangunan daerah, sebagai sumber daya penting untuk pengentasan kemiskinan melalui budaya pertanian dan pemprosesan selanjutnya.

Perkembangan industri kelapa sawit di Indonesia mengalami kemajuan yang pesat, terutama peningkatan luas lahan dan produksi kelapa sawit di Indonesia selama 10 tahun terakhir meningkat dari 22 juta Ha pada tahun 1997 menjadi 4,1 juta ha pada tahun 2007 atau meningkat 7,5 \% / tahun (Sunarko, 2009). Produktivitas CPO kelapa sawit meningkat dari 3.52 ton/ha pada tahun 2011 menjadi 5.37 ton/ha pada tahun 2012 dengan luasan 9 juta ha (Anonim, 2012).
Peningkatan luas areal tanaman kelapa sawit seringkali kurang memperhatikan kesesuaian lahan untuk kelapa sawit. Ketidak sesuaian lahan dapat menyebabkan terjadinya penurunan produktivitas tanaman kalapa sawit. Hal tersebut dapat dilihat dari adanya penurunan produktivitas minyak kelapa sawit (CPO) nasional pada tahun 2008 sebesar $11.54 \%$ dari tahun sebelumnya, yaitu dari 2.6 ton/ha menjadi 2.3 ton/ha (Anonim, 2009).

Untuk mencapai produksi yang tinggi tentunya peranan tenaga kerja dalam suatu perusahaan menjadi faktor yang sangat mendukung dalam meningkatkan produktivitas. Dengan meningkatkan produktivitas maka akan terjadi peningkatan langsung pada standar hidup (Setiowati, 2007). Produktivitas tenaga kerja berkaitan erat dengan kuantitas produksi yang akan dihasilkan. Dengan kata lain, apabila produktivitas yang dihasilkan oleh tenaga kerja yang digunakan tinggi akan menghasilkan produksi yang tinggi pula (Sinungan, 1992). 
Dalam teori Manajemen Sumber Daya Manusia (MSDM) terdapat faktor -faktor yang mempengaruhi produktivitas kerja. Menurut (Winaya, 1989) faktor-faktor yang mempengaruhi produktivitas tenaga kerja adalah pendidikan, keterampilan, disiplin, motivasi, sikap dan etika kerja, gizi dan kesehatan, gaji dan insentif (penghasilan), jaminan sosial, lingkungan dan iklim kerja, hubungan industrial, teknologi, sarana produksi, manajemen dan kesempatan berprestasi. Selanjutnya, menurut Hasibuan (2008), terdapat beberapa hal yang dapat mendorong produktivitas tenaga kerja, yaitu pelatihan dan pendidikan kerja, mutasi karyawan, pemeliharaan pekerja, pemberian penghargaan atau hukuman, pemberian motivasi kepada pekerja, adanya promosi atau demosi kepada pekerja, dan upah serta pemberian kompensasi kepada pegawai berupa insentif atau bonus. Secara ekonomi, produktivitas tenaga kerja juga dipengaruhi oleh faktor lain seperti umur, tingkat pendidikan, masa bekerja, jumlah tanggungan, dan gaji pokok (Manurung, 2012). Oleh sebab itu, peneliti tertarik untuk menganalisa apa saja faktorfaktor yang mempengaruhi produktivitas dari tenaga kerja pemanen kelapa sawit tersebut.

Berdasarkan uraian sebelumnya, maka dapat disusun permasalahan penelitian, yaitu : Faktor-faktor apa saja yang mempengaruhi kinerja pemanen untuk meningkatkan produktivitas yang tinggi.

Agar penelitian ini dapat dilakukan lebih fokus dan berjalan dengan sempurna maka perlu adanya batasan permasalahan variabel pada penelitian ini. Penelitian ini dibatasi pada umur, pendidikan, masa kerja, jumlah tanggungan.

Penelitian ini bertujuan untuk menganalisis pengaruh faktor umur, pendidikan, masa kerja, jumlah tanggungan terhadap produktivitas pemanen kelapa sawit.

Hasil yang diharapkan dari penelitian ini yaitu dapat memberikan masukan ke PT. Alam Jaya Persada tentang faktor-faktor apa sajakah yang dapat mempengaruhi produksi kelapa sawit di perusahaan tersebut.

Dapat memberikan informasi kepada masyarakat mengenai apasajakah faktor-faktor yang dapat mempengaruhi produktivitas tenaga kerja pemanen kalapa sawit di sebuah perusahaan kelapa sawit.

\section{METODE}

\section{A. Tempat dan Waktu Penelitian}

Penelitan ini dilaksanakan di PT. Alam Jaya Persada di kecamatan, Semboja, Kabupaten Kutai Kartanegara Provinsi Kalimantan Timur. Dengan lama waktu kurang lebih dua bulan terhitung mulai bulan Februari sampai dengan April 2019 yang meliputi persiapan alat dan bahan penelitian dan pengambilan data.

\section{B. Alat dan Bahan Penelitian}

Alat yang digunakan dalam penelitian ini terdiri dari kuisioner, wawancara, handphone (untuk merekam suara dan dokumentasi ) ATK, Laptop yang dilengkapi Microsoft Office 2010 dan Statistical Product and Service Solutions (SPSS). Adapun bahan yang digunakan dalam penelitian ini adalah data primer dan data sekunder

\section{Prosedur Penelitian}

\section{Persiapan}

Pada tahap ini, hal yang dilakukan adalah membuat kuesioner dan wawancara yang akan dibagikan pada setiap karyawan pemanen, serta mempersiapkan alat dan bahan yang diperlukan dalam penelitian tersebut.

2. Peninjauan Lapangan

Peninjauan lapangan meliputi kegiatan penentuan lokasi afdeling yang akan dijadikan bahan penelitian maupun gambar untuk keperluan skripsi

3. Pengambilan Data

Pengambilan data terdiri dari data primer dan data sekunder. Data primer yaitu data yang diperoleh dari hasil wawancara dan pengumpulan data dengan menggunakan kuesioner dan pengamatan serta diskusi di lapangan, sedangkan data sekunder yaitu Standar Operational Procedure (SOP) dan laporan perusahaan. (Data produksi kelapa sawit, umur, pendidikan, masa kerja, jumlah tanggungan).

\section{Pengolahan Data}

Dalam pengolahan data tersebut memeriksa data yang sudah didapat di lapangan kemudian diinput dalam bentuk tabel di Microsoft excel dengan menggunakan laptop. Setelah itu data diolah dengan menggunakan aplikasi SPSS, lalu hasil pengolahan data dianalisis kemudian dibahas 
dan dilakukan penarikan kesimpulan dan saran dari hasil penelitian

\section{Teknik Penentuan Sampel}

Penentuan sampel dalam penelitian ini dilakukan dengan jenis Non Probability sampling. Jenis ini tidak dipilih secara acak. Teknik Non Probability sampling yang dipilih yaitu dengan sampling jenuh (sensus) yaitu metode penarikan sampel bila semua anggota populasi dijadikan sebagai sampel. Hal ini sering dilakukan apabila jumlah populasi kecil, kurang dari 30 orang (Supriyanto dan Machfudz, 2010). Pada penelitian ini parameter pengamatan di batasi pada umur, pendidikan, masa kerja, jumlah tanggungan. Responden adalah karywan panen dengan status kerja sebagai karyawan harin tetap (KHT) sebanyak 20 responden.

\section{E. Teknik Analisis Data}

Untuk mengetahui adanya pengaruh beda nyata antara usia, pendidikan, masa kerja, jumlah tanggungan. Terhadap produktivitas tenaga kerja pemanen kelapa sawit, maka digunakan teknik analisa data regresi linear berganda. Penilaian hasil koesioner dilakukan dengan menggunakan scoring artinya masing-masing jawaban responden diberikan nilai dengan skala pengukuran atau penilaian menggunakan metode likert (Sugiono 2013),

- Jika jawaban responden STS (Sangat Tidak Setuju) maka diberi nilai 1

- Jika jawaban responden TS (Tidak Setuju) maka diberi nilai 2

- Jika jawaban responden N (Netral) maka diberi nilai 3

- Jika jawaban responden S (Setuju) maka diberi nilai 4

- Jika jawaban responden SS (Sangat Setuju) maka diberi nilai 5

1. Analisis regresi linier berganda

Untuk menjawab tujuan penelitian, yaitu mengetahui faktor-faktor yang mempengaruhi produktivitas tenaga kerja pemanen di perusahaan, digunakan metode analisis regresi berganda dengan alat bantu SPSS yaitu melihat pengaruh faktor umur (X1), pendidikan (X2), masa kerja (X3), jumlah tanggungan (X4). Terhadap produktifitas (Y) di PT. Alam Jaya Persada. Model regresi yang digunakan menurut Gujarati (1995) adalah :

Rumus metode regresi yaitu :

$$
\mathrm{Y}=\mathrm{a}+\mathrm{b} 1 \mathrm{X} 1+\mathrm{b} 2 \mathrm{X} 2+\mathrm{b} 3 \mathrm{X} 3+\mathrm{b} 4 \mathrm{X} 4+\mathrm{e}
$$

Dimana :

$\mathrm{Y}=$ Produktivitas tenaga kerja pemanen

$\mathrm{a}=$ Konstanta

bi\&ai $=$ Koefesien regresi $(i=1,2,3, \ldots .$.

n)

$\mathrm{X} 1=$ Umur

$\mathrm{X} 2=$ Pendidikan

$\mathrm{X} 3=$ Masa kerja

$\mathrm{X} 4=$ Jumlah tanggungan

$\mathrm{e}=$ Error

2. Sumbangan efektif (SE)

Menurut Hadi (2004), sumbangan efektif digunakan untuk mengetahui besarnya sumbangan atau kontribusi yang diberikan oleh tiap prediktor atau variabel bebas. Sumbangan efektif dapat dihitung dengan rumus sebagai berikut :

Keterangan

$$
\text { SE\% }=b x \times \text { rxy } \times 100
$$

SE : Sumbangan efektif dari 1 variabel

$\mathrm{Bx}$ : Koefisien regresi dari 1 variabel

Rxy : Koefisien korelasi dari 1 variabel

Perhitungan ini dilakukan agar dapat diketahui besarnya sumbangan masingmasing variabel bebas terhadap variabel terikat sehingga sumbangan yang diberikan masing-masing variabel dapat dilihat.

3. Uji Koefisien Determinasi

Koefisien determinasi merupakan alat untuk mengukur seberapa jauh kemampuan model dalam menerangkan varian variabel dependen. Nilai koefisien determinasi adalah antara 0-1. Nilai determinasi yang mendekati 0 berarti kemampuan variabel indenpenden dalam menjelaskan variabel dependen sangat lemah, dan sebaliknya jika nilai mendekati 1 maka kemampuan semakin kuat (Ghozali, 2009).

\section{HASIL DAN PEMBAHASAN}

\section{Identitas Responden}

Berdasarkan hasil dari kuesioner yang didapat di lapangan dapat dilihat bahwa Jumlah sampel dalam penelitian ini berjumlah 20 responden dibedakan atas beberapa karateristik identitas yaitu berdasarkan usia, jenis kelamin, tingkat pendidikan dan lama kerja responden.

a. Tingkat Usia/Umur

Adapun kisaran umur responden dalam penelitian ini dapat dilihat pada tabel berikut: 
Tabel 2. Jumlah Responden Berdasarkan Tingkat Usia

\begin{tabular}{ccc}
\hline Umur & Frekuensi & Presentase (\%) \\
\hline $10-20$ & 0 & $0 \%$ \\
$21-30$ & 6 & $30 \%$ \\
$31-40$ & 8 & $40 \%$ \\
$41-50$ & 6 & $30 \%$ \\
Total & 20 & $100 \%$ \\
\hline
\end{tabular}

Dari tabel 2 menjelaskan bahwa jumlah responden yang berumur 10-20 tahun $0 \%$, kemudian yang berumur 21-30 tahun berjumlah 6 orang atau $30 \%$ dari total jumlah responden, 31-40 tahun berjumlah 8 orang atau $40 \%$ dari total jumlah responden, $41-50$ tahun berjumlah 6 orang atau $35 \%$ dari jumlah responden.

Karyawan panen mayoritas antara 31-40 tahun yaitu sebanyak 8 orang atau sekitar $40 \%$ dimana pada usia tersebut merupakan usia yang produktif untuk bekerja. Dari hasil penelitian diperoleh data bahwa usia para karyawan panen adalah berkisar antara 31-40 tahun dapat dan dilihat pada tabel 2, dimana usia tersebut merupakan usia produktif karyawan dalam bekerja. Berkaitan dengan hal tersebut menurut Suparmoko (2002), yang menyatakan bahwa tenaga kerja yaitu orang yang berada didalam usia kerja, tenaga kerja dalam usia kerja yaitu berkisar 15-64 tahun. Tenaga kerja dalah penduduk pada usia kerja (15 tahun ke atas) atau 16-64 tahun dan secara potensial dapat bekerja dan jika mereka mau berpartisipasi dalam aktivitas tersebut (Sedermayanti 2016).

\section{b. Jenis Kelamin}

Adapun jenis kelamin responden dalam panelitian ini dapat dilihat pada tabel dibawah ini :

Tabel 3. Jenis kelamin responden

\begin{tabular}{ccc}
\hline $\begin{array}{c}\text { Jenis } \\
\text { Kelamin }\end{array}$ & Frekuensi & $\begin{array}{c}\text { Persentase } \\
(\%)\end{array}$ \\
\hline Laki-Laki & 20 & $100 \%$ \\
Perempuan & 0 & $0 \%$ \\
Total & 20 & $100 \%$ \\
\hline
\end{tabular}

Berdasarkan tabel 3 diatas terlihat bahwa responden seluruhnya adalah laki-laki sebanyak 20 responden atau $100 \%$. Dari hasil penelitian diperoleh data bahwa jenis kelamin para karyawa panen adalah mayoritas laki- laki hal ini diduga laki-laki lebih kuat dibandingkan perempuan hal tersebut berkaitan dengan teori Menurut Fakih (1999), menyatakan bahwa ciri-ciri dari sifat gender menyatakan bahwa perempuan dikenal dengan leman lembut, cantik, emosional dan ke ibuan. Sementara laki-laki dianggap kuat rasional jantan dan perkasa.

\section{c. Tingkat Pendidikan}

Adapun rata-rata pendidikan responden dalam penelitian ini dapat dilihat pada tebel di bawah ini :

Tabel 4. Tingkat Pendidikan Responden

\begin{tabular}{ccc}
\hline Pendidikan & Frekuensi & Presentase(\%) \\
\hline SD & 13 & $65 \%$ \\
SMP & 3 & $15 \%$ \\
SMA/SMK & 4 & $20 \%$ \\
D3 & - & - \\
S1,S2 & - & - \\
\hline Total & 20 & $100 \%$ \\
\hline
\end{tabular}

Dari tabel 4 dapat dijelaskan bahwa tingkat pendidikan responden terakhir dari jawaban responden ada 13 responden yang tamat SD atau $65 \%$ dari total jumlah responden, dan SMP ada 3 responden atau $15 \%$ dari total jumlah responden, kemudian responden yang tamat SMA/SMK 4 responden atau $20 \%$ dari total jumlah responden, dan responden D3,S1 dan S2 ada $0 \%$ dari total keseluruhan responden.

Dari uraian tersebut dapat diketahui bahwa mayoritas tingkat pendidikan karyawan panen adalah SD yaitu sebanyak 13 orang atau $65 \%$.

Dari hasil penelitian dilihat dari segi pendidikan para karyawan panen yaitu SD sebanyak 13 orang untuk hal ini diduga dimana tingkat pendidikan tersebut sudah cukup untuk mengerjakan pekerjaannya dengan baik. Dengan hal tersebut barkaitan dengan teori menurut Sumarsono (2003), pada umumnya orang yang memiliki pendidikan akan mempunyai wawasan yang lebih luas dan kesadaran akan pentingnya produktivitas. Tingkat pendidikan seorang karyawa mampu meningkatkan daya saing perusahaan dan memperbaiki kinerja suatu perusahaan (Hariandja, 2002). 
d. Lama Kerja Responden

Adapun rata-rata lama kerja responde dalam penelitian ini dapat dilihat pada tebel di bawah ini :

Tabel 5.Lama kerja responden

\begin{tabular}{ccc}
\hline Lama kerja & Jumlah & Presentase \\
\hline$\leq 1$ tahun & 11 & $55 \%$ \\
$1-5$ tahun & 6 & $30 \%$ \\
$6-10$ tahun & 3 & $15 \%$ \\
$11-15$ tahun & - & $0 \%$ \\
$16-20$ tahun & - & $0 \%$ \\
\hline Total & 20 & $100 \%$ \\
\hline
\end{tabular}

Dari tabel 5 menjelaskan tentang lama kerja responden pada perusahaan. Responden yang bekerja dibawah $\leq 1$ tahun berjumlah 11 orang atau $55 \%$ dari total responden, dan selanjutnya yang bekerja antara 1-5 tahun berjumlah 6 orang atau $30 \%$ dari total jumlah responden, $6-10$ tahun berjumlah 3 orang atau $15 \%$ dari total responden, $11-15$ berjumlah $0 \%$ dari total responden dan 16-20 tahun berjumlah 0\% dari total responden. Dari uraian diatas dapat dilihat bahwa mayoritas lama kerja karyawan panen adalah $\leq 1$ tahun yaitu sebanyak 11 orang atau $55 \%$.

Hasil penelitian lama kerja para karyawan panen yaitu berkisar kurang dari 1 tahun berjumlah 11 orang untuk hal ini diduga, dimana semakin lama karyawan panen bekerja maka akan semakin bertambah pengalam kerjanya. Dalam hal tersebut berkaitan dengan teori menurut Ranupendoyo dan Saud (2005), menyatakan bahwa semakin lama individu bekerja pada sebuah perusahaan maka individu tersebut akan semakin berpengalaman. Semakin lama tenaga kerja bekerja, maka semakin banyak pengalaman yang dimiliki oleh tenaga kerja. Banyaknya pengalaman dalam bekerja memberikan tenaga kerja keahlian dan mendorong tenaga kerja untuk dapat meningkatkan produktivitas kerjanya (Van den ban dan Hawkins, 1999).

Hasil penelitian diduga kerena setiap responden memiliki karateristik yang berbeda-beda seperti usia, pendidikan, jenis kelamin dan lama kerja. Penelitian ini memperkuat kajian teori menurut Robbinson (2006), karateristik undividu mencakup usia, jenis kelamin, tingkat pendidikan, status perkawinan dan lama bekerja dalam sebuah perusahaan.

\section{Hasil Analisis Data}

\section{a. Analisis Regresi Linear Berganda}

Hasil dari perhitungan untuk analisis regresi dari responden dapat dilihat pada tabel dibawah ini :

Tabel 6. Rekapitulasi Regresi Linear Berganda

\begin{tabular}{lrr}
\hline Variabel & \multicolumn{2}{l}{$\begin{array}{c}\text { B (koefisien } \\
\text { regresi) }\end{array}$} \\
\hline (Constant) & 24,675 & \\
Umur & 0,190 & 0,202 \\
Pendidikan & 0,150 & 0,155 \\
Masa kerja & $-0,136$ & $-0,200$ \\
Jumlah & & \\
tanggungan & $-0,172$ & $-0,450$ \\
\hline $\mathrm{N}=20$ & & \\
$\mathrm{R}=0,646$ & & \\
$\mathrm{R}$ Square $\left(\mathrm{R}^{2}\right)=0,417$ & & \\
\hline
\end{tabular}

Hasil analisa dan persamaan regresi diatas, maka dapat diinterpretasikan sebagai berikut:

1) $A=$ konstanta

Nilai konstanta sebesar 24,657. Hal ini dapat diinterpretasikan bahwa apabila variabel umur $(X 1)$, variabel pendidikan $(X 2)$, variabel masa kerja (X3), variabel jumlah tanggungan (X4) belum memberikan kontribusi, maka produktivitas karyawan pada PT. Alam Jaya Persada adalah sebesar 24,657.

2) b1= koefisien regresi umur (X1)

Nilai koefisien regresi $X 1$ sebesar 0,190. Hal ini dapat diinterpretasikan bahwa variabel umur (X1) mempengaruhi produktivitas kerja karyawan sebesar 0,190 artinya apabila setiap peningkatan umur (X1) sebesar satu satuan, maka akan meningkatkan produktivitas karyawan sebesar 0,190 dengan asumsi variabel lain tetap.

3) b2= koefisien regresi pendidikan (X2)

Nilai koefisien regresi X2 sebesar 0,150. Hal ini dapat diinterpretasikan bahwa variabel pendidikan (X2) mempengaruhi produktivitas kerja karyawan sebesar 0,150 artinya apabila setiap peningkatan pendidikan (X2) sebesar satu satuan, maka akan meningkatkan produktivitas pendidikan 0,150 dengan asumsi variabel yang lain tetap. 
4) b3= koefisien regresi masa kerja (X3)

Nilai koefisien regresi $X 3$ sebesar 0,136 . Hal ini dapat diinterpretasikan bahwa variabel masa kerja (X3) mempengaruhi produktivitas kerja karyawan sebesar $-0,136$ artinya apabila setiap peningkatan masa kerja (X3) sebesar satu satuan, maka akan menurunkan produktivitas kerja karyawan sebesar $-0,136$ dengan asumsi variabel yang lain tetap.

5) b4= koefisien regresi jumlah tanggungan (X4)

Nilai koefisien regresi X4 sebesar 0,172 . Hal ini dapat diinterpretasikan bahwa variabel jumlah tanggungan (X4) mempengaruhi produktivitas kerja karyawan sebesar $-0,172$ artinya apabila setiap peningkatan jumlah tanggngan (X4) sebesar satu satuan, maka akan menurunkan produktivitas kerja karyawan sebesar $-0,172$ dengan asumsi variabel yang lain tetap.

\section{b. Uji Kontribusi Variabel}

1) Uji Sumbangan Efektif (SE) Uji sumbangan efektif ini digunakan untuk mengetahui kontribusi yang diberikan oleh masing-masing variabel bebas terhadap variabel terikat. Syarat untuk dapat menghitung sumbangan efektif adalah dengan memiliki hasil analisis korelasi dan regresi pada masing-masing variabel bebas. Tabel 7. hasil uji Sumbangan Efektif (SE)

\begin{tabular}{ccccc}
\hline Variabel & $\begin{array}{c}\text { Koefisien } \\
\text { regresi } \\
\text { (Beta) }\end{array}$ & $\begin{array}{c}\text { Koefisien } \\
\text { korelasi }(r)\end{array}$ & $\begin{array}{c}\text { Sumb } \\
\text { angan } \\
\text { efektif } \\
(\%)\end{array}$ & $\begin{array}{c}\mathrm{R} \\
\text { Square } \\
\left(\mathrm{R}^{2}\right)\end{array}$ \\
\hline $\begin{array}{c}\text { Umur (X1) } \\
\begin{array}{c}\text { Pendidikan } \\
(\mathrm{X})\end{array}\end{array}$ & 0,202 & 0,187 & 3,77 & \\
$\begin{array}{c}\text { Masa kerja } \\
(\mathrm{X})\end{array}$ & 0,155 & 0,111 & 1,72 & $41,7 \%$ \\
$\begin{array}{c}\text { Jumlah } \\
\text { tanggunga } \\
\mathrm{n}(\mathrm{X} 4)\end{array}$ & $-0,200$ & $-0,469$ & 9,92 & \\
\hline
\end{tabular}

Dari tabel 17 dapat dijelaskan bahwa berdasarkan data di atas, maka dapat diketahui bahwa besar sumbangan yang diberikan oleh variabel pendidikan (X1) sebesar $3,77 \%$ atau dapat dikatakan bahwa variabel pendidikan (X1) ini memberikan kontribusi terhadap peningkatan variabel produktivitas $(Y)$ sebesar 3,77. Sedangkan besar nilai sumbangan yang diberikan oleh variabel pendidikan (X2) adalah sebesar 1,72\% atau dapat dikatakan bahwa variabel pendidikan (X2) memberikan kontribusi terhadap peningkatan variabel produktivitas $(\mathrm{Y})$ sebesar 1,72\%. Sedangkan besar nilai sumbangan yang diberikan oleh variabel masa kerja (X3) adalah sebesar 9,92\% atau dapat dikatakan bahwa variabel masa kerja (X3) memberikan kontribusi terhadap peningkatan variabel produktivitas (Y) sebesar 9,92\%. Sedangkan besar nilai sumbangan yang diberikan oleh variabel jumlah tanggungan (X4) adalah sebesar $26,28 \%$ atau dapat dikatakan bahwa variabel jumlah tanggungan (X4) memberikan kontribusi terhadap peningkatan variabel produktivitas (Y) sebesar 26,28. Sehingga dapat dikatakan diantara variabel umur (X1), pendidikan (X2), masa kerja (X3) jumlah tanggungan dan (X4) yang memiliki kontribusi paling dominan adalan masa kerja (X4).

\section{Dari hasil penelitian hasil Uji regresi liniear berganda dan Uji sumbangan efektif.}

\section{a. Pengaruh faktor umur terhadap produktivitas kerja karyawan}

Berdasarkan hasil uji regresi liniear berganda menunjukan bahwa umur memiliki pengaruh positif terhadap produktivitas kerja karyawan di PT. Alam Jaya Persada dan dari hasil uji sumbangan efektif juga menunjukan bahwa umur memiliki kontribusi sebesar 3,77\% terhadap peningkatan produktivitas karyawan. Hal ini diduga umur mempengaruhi kemampuan fisik seseorang dan cara berfikir seorang karyawan. Secara umum dapat dilihat bahwa karyawan yang berusia mudah dan sehat akan memiliki kemapuan fisik sehingga dapat meningkatkan produktivitas.

Berdasarkan hasil penelitian tingkat umur responden rata-rata yang tertinggi berada pada usia 31-40 yaitu sebanyak 8 orang (40\%), maka dari itu jumlah karyawan panen berada pada umur yang produktif yang artinya karyawan tersebut masih memiliki fisik yang kuat dan 
semangat kerja yang tinggi dan pencapaian target yang telah ditentukan oleh perusahaan. Hal ini sesuai dengan pendapat Herawati (2013), bahwa semakin bertambahnya umur maka semakin produktif, karena dianggap memiliki pengalaman kerja yang lebih banyak dibandingkan dengan yang masih mudah. $\mathrm{Hal}$ ini sejalan dengan hasil penelitian sebelumnya yang dilakukan oleh Jumliati (2016), menunjukan bahwa umur berpengaruh positif terhadap produktivitas.

\section{b. Pengaruh faktor pendidikan terhadap produktivitas kerja karyawan}

Berdasarkan hasil uji regresi liniear berganda menunjukan bahwa pendidikan memiliki pengaruh positif terhadap produktivitas kerja karyawan PT. Alam Jaya Persada dan dari hasil uji sumbangan efektif juga menunjukan bahwa pendidikan memiliki kontribusi sebesar 1,72\% terhadap peningkatan produktivitas karyawan. pendidikan yang dimiliki seseorang sangat penting karena dapat menangani kasus tertentu dilapangan dan mengerti dalam melaksanakan pekerjaannya.

Hal ini sejalan dengan teori dari Ravianto (2005), menjelaskan bahwa pendidikan membentuk dan menambah pengatahuan seseorang untuk mengerjakan sesuatu dengan lebih cepat dan tepat.

Hal ini sejalan dengan penelitian yang dilakukan oleh Florencia Pandanwangi (2007), yang mengatakan bahwa pendidikan berpengaruh positif terhadap prestasi karyawan karyawan.

\section{c. Pengaruh faktor masa kerja terhadap produktifitas kerja karyawan}

Berdasarkan hasil uji regresi liniear berganda menunjukan bahwa masa kerja memiliki pengaruh negatif terhadap produktivitas kerja karyawan PT. Alam Jaya Persada dan dari hasil uji sumbangan efektif juga menunjukan bahwa masa kerja memiliki kontribusi sebesar 9,92\% terhadap peningkatan produktivitas karyawan. Dari hasil penelitian masa kerja karyawan rata-rata dibawah 1 tahun sehingga masa kerja ini belum mempu meningkatkan produktivitas dikarenakan belum banyak pengalaman yang didapat.
Hal ini sejalan dengan dengan pernyataan Manulang (2000), bahwa masa kerja adalah proses pembentukan pengetahuan atau keterampilan tentang metode suatu pekerjaan karena keterlibatan karyawan tersebut dalam pelaksanaan tugas pekerjaan. Hal ini sejalan dengan penelitian yang dilakukan oleh Septi nur afifa dan Iskandar lubis (2016), masa kerja akan mempengaruhi tingkat keterampilan dan pengalaman kerja dan diikuti dengan peningkatan kinerja sehingga produktivitas pun akan mengingkat.

\section{d. Pengaruh faktor jumlah tanggungan terhadap produktivitas kerja karyawan}

Berdasarkan hasil uji regresi liniear berganda menunjukan bahwa jumlah tanggungan memiliki pengaruh negatif terhadap produktivitas kerja karyawan PT. Alam Jaya Persada dan dari hasil uji sumbangan efektif juga menunjukan bahwa jumlah tanggungan memiliki kontribusi sebesar $26,28 \%$ terhadap peningkatan produktivitas karyawan. Dari hasil penelitian dilihat bahwa jumlah tanggungan pada setiap karyawan tidak berpengaruh, hal ini dipengaruhi jumlah tanggungan keluarga pemanen sedikit sehingga buru panen tidak termotivasi untuk meningkatkan kinerjanya untuk memenuhi kebutuhan hidup atau beban tanggungannya.

Hal ini sejalan dengan hasil penelitian sebelumnya yang dilakukan oleh Jumliati (2016), menunjukan bahwa jumlah tanggungan berpengaruh negatif terhadap produktivitas.

Hal ini tidak sejalan dengan pernyataan Van den ban dan Hawkins (1999), bahwa semakin banyak jumlah tanggungan maka semakin banyak tekanan bagi tenaga kerja untuk membiayai kebutuhan keluarganya. Jumlah tanggungan yang semakin tinggi akan mendorong tenaga kerja bekerja lebih giat dan mendorong produktivitas kerja.

2) Uji Sumbangan Efektif (SE)

Uji koefisien determinasi digunakan untuk mengetahui seberapa besar persentase pengaruh yang diberikan variabel bebas terhadap perubahan 
variabel terikat secara bersama-sama. Dari perhitungan hasil uji koefisien determinasi $\left(R^{2}\right)$ dapat dilihat bahwa nilai dari koefisien determinasi $\left(R^{2}\right)$ sebesar 0,417 atau $41,7 \%$. Hal itu menunjukkan bahwa besarnya pengaruh yang diberikan variabel bebas yaitu umur (X1) pendidikan (X2) masa kerja (X3) jumlah tanggungan (X4) terhadap variabel terikat yaitu produktivitas (Y) sebesar 41,7\% sedangkan sisanya yaitu $58,3 \%$ dipengaruhi oleh variabel lain di luar variabel penelitian.

Presentase variabel umur, pendidikan, masa kerja dan jumlah tanggungan yaitu pada $R$ squre $\left(\mathrm{R}^{2}\right)$ sebesar 0,417, dalam hal ini dapat diartikan bahwa faktor tenga kerja karyawan panen dapat dipengaruhi oleh faktor umur, pendidikan, masa kerja dan jumlah tanggungan dengan presentase sebesar 0,417 atau $41,7 \%$ sedangkan sisanya sebesar $58,3 \%$ dipengaruhi oleh variabel lain yang tidak diteliti dalam penelitian ini atau dapat disimpulkan bahwa antara variabel umur, pendidikan, masa kerja dan jumlah tanggungan terhadap produktivitas kerja karyawan mempunyai hubungan yang kuat. hal ini berkaitan dengan dengan kajian teori menurut Ghozali (2016), uji koefisien determinasi bertujuan untuk mengukur sejauh mana model menjelaskan variabel terikat. Nilai koefisien determinasi yaitu antara nol dan satu. Berikut penjelasan mengenai nilai koefisien determinasi : 0 (tidak ada korelasi), 0-0,49 (korelasi lemah), 0,50 (korelasi moderat), 0,51-0,99 (korelasi kuat) dan 1 (korelasi sempurna).

\section{KESIMPULAN}

Dari hasil penelitian yang dilakukan maka dapat ditarik suatu kesimpulan sebagai berikut :

1. Dari hasil uji regresi linear berganda menunjukan bahwa faktor umur berpengaruh positif terhadap produktivitas kerja karyawan dan dari hasil uji sumbangan efektif juga menunjukan bahwa umur memiliki kontribusi sebesar $3,77 \%$ terhadap peningkatan produktivitas karyawan
2. Dari hasil uji regresi linear berganda menunjukan bahwa faktor pendidikan berpenaruh positif terhadap produktivitas kerja karyawan dan dari hasi uji sumbangan efektif juga menunjukan bahwa pendidikan memiliki kontribusi sebesar $1,72 \%$ terhadap peningkatan produktivitas karyawan.

3. Dari hasil uji regresi linear berganda menunjukan bahwa faktor masa kerja berpengaruh negatif terhadap produktivitas kerja karyawan dan dari hasil uji sumbangan efektif juga menunjukan bahwa masa kerja memiliki kontribusi sebesar 9,92\% terhadap peningkatan produktivitas karyawan.

4. Dari hasil uji regresi linear berganda menunjukan bahwa faktor jumlah tanggungan berpengaruh negatif terhadap produktivitas kerja karyawan dan dari hasil uji sumbangan efektif juga menunjukan bahwa jumlah tanggungan memiliki kontribusi sebesar 26,28\% terhadap peningkatan produktivitas karyawan.

5. Berdasarkan hasil dari uji koefisien determinasi faktor umur, pendidikan, masa kerja, jumlah tanggungan secara bersamasama memiliki pengaruh sebesar $41,7 \%$ dan tingkat hubungan yang terjalin antar keempat variabel tersebut sangat kuat.

\section{DAFTAR PUSTAKA}

Anonim. (2009). Statistika Perkebunan Indonesia kelapa sawit. Jakarta: Direktorat Jenderal Perkebunan.

Anonim. (2012). Luas areal kelapa sawit menurut provinsi di indonesia. 2008-2012 http://www.deptan.go.it (di unduh 10 juli 2013)

Arikunto. (1999). Prosedur Penelitian Suatu Pendekatan Praktis. Jakarta: Rineka Cipta.

Hariandja dan Maribot T,E. (2002). Manajemen Sumber Daya Manusia. Jakarta.

Hasibuan. (2008). Manajemen Sumber Daya Manusia. Jakarta: Bumi Aksara.

Herawati dan Titin. (2013). Pengaruh KebijakanDiveden, Kebijakan Hutang, dan Profitabilitas, terhadap nilai perusahaan. Padang: Universitas Negeri Padang.

Jumliati. (2016). Faktor-faktor yang mempengaruhi produktivitas tenaga kerja industri roti morasa dikabupaten moras. 
Skripsi Fakultas Ekonomi. Makassar: Universitas Negeri Makkasar.

Manulang. M. (2000). Dasar-Dasar Manajemen. Ghalia, Jakarta.

Manurung dan Ramadhani S. (2012). Faktor Faktor Yang Mempengaruhi Produktivitas Tenaga Kerja Karyawan Pemanen Dan Pemupuk Di PT. Perkebunan Nusantara IV. Skripsi. Fakultas Pertanian. Universitas Sumatra

Pandawangi, P. (2007). Pengaruh tingkat pendidikan, usia dan pengalaman kerja tehadap prestasi kerja karyawan, Fakultas Ekonomi. Yogyakarta: Universitas Sanata Dhrma Yogyakarta.

Ranupendoyo dan Saud. (2005). Manajemen Personalia. Yogyakarta.

Ravianto, J. (1990). Produktivitas dan pengukuran. Jakarta

Robinson, T. (2006). Ekonomi Regional. Teori dan aplikasi. Medan: PT. Bumi Angkasa.

Setiowati. (2007). Faktor-Faktor yang Berhubungan dengan Produktivitas dan Kontribusi Penghasilan Tenaga Kerja Wanita Pemetik Teh Di PTP. Nusantara VI Kayu Aro Kabupaten Kerinci Propinsi Jambi. Skripsi. Jurusan Sosial Ekonomi Pertanian, Fakultas Pertanian, Universitas Bengkulu (tidak dipublikasikan).

Sinungan, M. (1992). Manajemen Modern. Jakarta: Gunung Agung.

Suparmoko, M. (2002). Ekonomi Publik, Untuk Keuangan dan Pembangunan Daerah. Yogyakarta.

Sedarmayanti, M. (2016). Manajemen Sumber Daya Manusia : Edisi Revisi. Bandung: PT. Refika Aditama.

Sumarsono, S. (2003). Ekonomi Manajemen Sumber Daya Manusia dan Ketenagakerjaan. Yogyakarta: Graha ilmu.

Winaya dan Kuna. (1989). Manajemen Sumber Daya Manusia (Lanjutan) edisi ketiga. Denpasar: Fakultas Ekonomi Universitas Udayana. 